Al-Khwarizmi: Jurnal Pendidikan Matematika dan Ilmu Pengetahuan Alam Maret-2020, Vol.8, No.1, hal.23-38

$\operatorname{ISSN}(P):$ 2337-7666; ISSN(E):2541-6499

https://ejournal.iainpalopo.ac.id/index.php/al-khwarizmi

DOI: http://dx.doi.org/10.24256/jpmipa.v8i1.800

\title{
Analisis Kemampuan Siswa dalam Pembuktian Kesebangunan Dua Segitiga
}

\author{
Yayan Eryk Setiawan \\ Program Studi Pendidikan Matematika, FKIP, Universitas Islam Malang \\ Jl. Mayjen Haryono 193 Malang, 65144 \\ Email:yayaneryksetiawan@unisma.ac.id
}

Article History:

Received: 27-08-2019; Received in Revised: 21-03-2020; Accepted: 28-03-2020

\begin{abstract}
Mathematics learning in junior high is inseparable from proof, including of congruence of two triangles. This study analyzes the ability to prove the similarity of two triangles. The procedure used (1) grouped the answers of 51 students based on categories of able, underprivileged and unable, (2) analyzing the ability of evidence-based basic mathematical knowledge, representation of evidence, and assumptions used. The result (1). students who can prove have basic knowledge of the Pythagoras theorem, algebra operations, and the principle of equality, the representations used are symbolic and formal evidence, the assumptions used are logical. (2) Students who are unable to prove to have basic knowledge of congruence, comparison, and the principle of equality, the representation used is visual and formal evidence, the assumptions used are logical. (3) Students who have not been able to prove to have the basic knowledge that is not relevant in supporting evidence, the representation used is symbolic evidence but is wrong in algebraic manipulation and informal evidence, students' assumptions are lacking or illogical.
\end{abstract}

Keywords: Similarity of two triangles.; The ablitiy to Prove.

\begin{abstract}
Abstrak
Pembelajaran matematika di SMP tidak terlepas dari pembuktian termasuk kesebangunan dua segitiga. Penelitian ini menganalisis kemampuan siswa dalam membuktikan kesebangunan dua segitiga. Prosedur yang digunakan (1) mengelompokkan jawaban 51 siswa berdasarkan kategori mampu, kurang mampu dan belum mampu, (2) menganalisis kemampuan pembuktian berdasarkan pengetahuan matematis dasar, representasi bukti, serta asumsi yang digunakan. Diperoleh hasil bahwa (1). siswa yang mampu membuktikan memiliki pengetahuan dasar teorema Pythagoras, operasi aljabar, dan prinsip kesetaraan, representasi yang digunakan berupa bukti simbolis dan formal, asumsi yang digunakan adalah logis. (2) Siswa yang kurang mampu membuktikan memiliki pengetahuan dasar kesebangunan, perbandingan, dan prinsip kesetaraan, representasi yang digunakan adalah bukti visual dan formal, asumsi yang digunakan adalah logis. (3) Siswa yang belum mampu membuktikan memiliki pengetahuan dasar yang tidak relevan dalam mendukung pembuktian, representasi yang digunakan adalah bukti simbolis, tetapi salah dalam manipulasi aljabar dan bukti tidak formal, asumsi siswa kurang atau tidak logis.
\end{abstract}

Kata Kunci: Kesebangunan Dua Segitiga; Kemampuan dalam Pembuktian. 


\section{Pendahuluan}

Pembelajaran matematika di sekolah tidak terlepas dari pembuktian, terutama pada materi geometri. Alasan mengapa pembuktian perlu dibejarkan kepada siswa adalah untuk mengembangkan kapasitas dan disposisi siswa dalam membuat kesimpulan yang diperlukan dari kemungkinan yang diberikan dan sebagai alat yang sangat berharga untuk pemecahan masalah matematis ${ }^{1}$. Pembuktian dalam matematika adalah bagian dari materi pelajaran yang mengikat guru dan siswa, dimana pembuktian harus dibelajarkan, dipelajari, diketahui, dan dinilai ${ }^{2}$. Selain itu, penalaran dan pembuktian harus menjadi bagian yang konsisten dari pengalaman matematika siswa di sekolah taman kanak-kanak sampai kelas $12^{3}$. Kata pembuktian dalam dokumen NCTM dihubungkan dengan penalaran, karena dalam penarikan kesimpulan (penalaran) membutuhkan bukti. Jadi pembuktian dalam pembelajaran matematika adalah hal penting dalam mengembangkan kemampuan dan disposisi seseorang dalam membuat kesimpulan.

Bagaimana dengan pembelajaran matematika di Indonesia? Pembelajaran matematika di Indonesia sudah menerapkan pembuktian pada siswa kelas 9 sekolah menengah pertama, yaitu materi kesebangunan dan kekongruenan bangun datar ${ }^{4,5}$. Pembelajaran tentang pembuktian di jenjang sekolah menengah pertama juga dapat diketahui dari guru matematika sekolah menengah pertama yang mengajarkan tentang pembuktian dalam materi kesebangunan dan kekongruenan. Selain itu mengenai pembuktian dapat kita ketahui dari buku-buku matematika yang banyak digunakan di Indonesia, yaitu buku Kurikulum Tingkat Satuan Pendidikan 2006 dan buku Kurikulum 2013. Jadi kurikulum di Indonesia telah menerapkan pembuktian di jenjang sekolah menengah pertama, yaitu pada materi kesebangunan dan kekongruenan bangun datar baik segitiga maupun segiempat.

${ }^{1}$ Despina A. Stylianou, Maria L. Blanton, and Eric J. Knuth, eds., Teaching and Learning Proof Across the Grades: A K-16 Perspective, 1 edition (New York: Routledge, 2009), 250-68.

2 Ibid., 40-63.

${ }^{3}$ Research Advisory Committee of the National Council of Teachers of Mathematics, "NCTM Curriculum and Evaluation Standards for School Mathematics: Responses from the Research Community," Journal for Research in Mathematics Education 19, no. 4 (1988): 33844, https://doi.org/10.2307/749544.

${ }^{4}$ Wahyudin Djumanta and Dwi Susanti, Belajar Matematika Aktif Dan Menyenangkan (Jakarta: Grasindo, 2008).

${ }^{5}$ Subchan et al., Matematika SMP/MTs Kelas IX - Semester 1 - Kurikulum 2013 - Edisi Revisi 2015 (Jakarta: Kementerian Pendidikan dan Kebudayaan, 2018), https://www.myedisi.com/bse/25202/matematika. 
Pembuktian dalam matematika mengacu pada pembuktian deduktif, yaitu proses penarikan kesimpulan dari umum ke khusus. Pembuktian deduktif yang digunakan untuk menunjukkan bahwa suatu pernyataan benar dilakukan dengan menerapkan hasil matematis dan/atau pemahaman yang lain ke dalam struktur matematis yang terbentuk di dalam pernyataan yang akan dibuktikan ${ }^{6}$. Misalnya, buktikan bahwa penjumlahan dua bilangan genap adalah bilangan genap. Untuk membuktikan pernyataan ini kita menerapkan pemahaman lain, yaitu definisi bilangan genap (yaitu misalnya dua bilangan genap $2 k_{1}$ dan $2 k_{2}$ ) dan menerapkan hasil matematis yang berupa penjumlahan dan sifat distributif, yaitu $2 k_{1}+2 k_{2}=2\left(k_{1}+k_{2}\right)$. Karena $2\left(k_{1}+k_{2}\right)$ merupakan bilangan yang dapat dibagi 2 , maka terbukti bahwa penjumlahan dua bilangan genap adalah genap. Selain itu dalam pembuktian juga dibutuhkan representasi, dimana representasi pembuktian bisa berupa bukti visual, bukti simbolis dan bukti formal ${ }^{7}$. Representasi bukti visual bisa melibatkan grafik atau gambar, representasi bukti simbolis bisa menggunakan manipulasi simbol-simbol aljabar, dan representasi bukti secara formal adalah bukti yang bersifat umum (lihat pada Tabel 1).

Tabel 1. Bukti Bersifat Umum

\begin{tabular}{ll}
\hline Pernyataan & \multicolumn{1}{c}{ Deskripsi } \\
\hline $\begin{array}{l}\text { Bukti } \\
\text { bersifat }\end{array}$ & $\begin{array}{l}\text { 1. Dapat membuktikan bahwa suatu pernyataan yang } \\
\text { diberikan benar untuk setiap kemungkinan, merupakan } \\
\text { bukti. }\end{array}$ \\
& $\begin{array}{l}\text { 2. Pembuktian dapat dilakukan dengan bukti langsung, } \\
\text { bukti tidak langsung, bukti visual atau gambar, dimana } \\
\end{array}$ \\
& $\begin{array}{l}\text { semua pernyataan atau gambar mengacu kepada kondisi } \\
\text { yang diberikan, merupakan bukti. }\end{array}$ \\
& 3. Bukti empiris dari satu atau lebih kasus bukan \\
& merupakan bukti. \\
& 4. $\begin{array}{l}\text { Memeriksa beberapa kasus kritis tertentu bukan } \\
\text { merupakan bukti. }\end{array}$
\end{tabular}

Adaptasi: Mccrone \& Tami (2009: 205)

Apabila dalam pembuktian menggunakan asumsi dasar, maka asumsi yang digunakan harus matematis dan logis. Asumsi matematis adalah berupa definisi dan aksioma, sedangkan asumsi logis adalah aturan penarikan kesimpulan yang logis ${ }^{8}$. Jadi dalam pembuktian deduktif diperlukan tiga hal, yaitu pengetahuan matematis, representasi bukti, dan asumsi yang digunakan.

6 Eric J. Knuth, "Secondary School Mathematics Teachers' Conceptions of Proof," Journal for Research in Mathematics Education, 2002, 379-405.

7 David Tall, "Cognitive Development, Representations and Proof," in Proceedings of the Conference Justifying and Proving in School Mathematics, vol. 27, 1995, 38.

8 Paul Ernest et al., "The Philosophy of Mathematics Education," 1991. 
Selain pengetahuan matematis, representasi bukti, dan asumsi yang digunakan dalam pembuktian, juga diperlukan untuk memperhatikan aturanaturan pembuktian secara formal. Misalnya pembuktian dalam geometri secara formal dilakukan dengan mengikuti aturan dua kolom, yaitu kolom kanan dan kolom kiri. Kolom kiri berisi pernyataan dan kolom kanan berisi alasan-alasan'. Akan tetapi, pembuktian secara formal dengan menggunakan dua kolom tersebut jarang dilakukan di sekolah menengah pertama maupun sekolah menengah atas. Pembuktian di sekolah tidak menggunakan dua kolom tersebut, tetapi pembuktian menggunakan pernyataan dan disamping pernyataan tersebut ditulis alasan-alasannya, sehingga pembuktian dilakukan apa adanya ${ }^{10}$.

Meskipun pembuktian dilakukan apa adanya, akan tetapi hasil penelitian tentang pembuktian menunjukkan bahwa $50 \%$ dari 52 siswa sekolah menengah pertama tidak menyukai masalah pembuktian ${ }^{11}$. Penelitian sebelumnya tentang pembuktian pada materi kesebangunan dua segitiga menunjukkan bahwa dari 56 siswa kelas IX sekolah menangah pertama, terdapat 24 siswa dapat memberikan bukti dengan benar, 5 siswa memberikan bukti kurang lengkap dan 27 siswa memberikan bukti salah ${ }^{12}$. Hasil tersebut telah menunjukkan bahwa siswa sekolah menengah pertama ada yang mampu melakukan pembuktian, yaitu dapat memberikan bukti dengan benar, kurang mampu melakukan pembuktian, yaitu bukti yang diberikan kurang lengkap, dan belum mampu melakukan pembuktian, yaitu bukti yang diberikan salah. Peluang penelitian lanjutan dari hasil penelitian tersebut adalah mengetahui bagaimana kemampuan pembuktian siswa berdasarkan kategori siswa mampu, kurang mampu, dan belum mampu dalam melakukan pembuktian pada materi kesebangunan dua segitiga.

Sesuai dengan penelitian lanjutan tersebut, penelitian ini bertujuan untuk mengetahui kemampuan siswa sekolah menengah pertama dalam membuktikan kesebangunan dua segitiga. Dengan diketahuinya kemampuan siswa dalam melakukan pembuktian pada materi kesebangunan dua segitiga, maka diharapkan guru matematika di Sekolah Menengah Pertama dapat membelajarkan pembuktian pada materi kesebangunan dua segitiga secara

${ }^{9}$ Stylianou, Blanton, and Knuth, Teaching and Learning Proof Across the Grades.

10 Ibid.

11 Yayan Eryk Setiawan and Sunardi, "Profil Keterampilan Berpikir Kritis Siswa SMP," vol. 1 (Prosiding Seminar Nasional Pendidikan Matematika "Pengembangan 4C's dalam Pembelajaran Matematika: Sebuah Tantangan Pengembangan Kurikulum Matematika," Malang: Program Studi S2-S3 Pendidikan Matematika Pascasarjana Universitas Negeri Malang, 2016), 933-42, https://scholar.google.co.id/citations?user=eo91IMAAAAJ\&hl=en\#d=gs_md_cita-

$\mathrm{d} \& \mathrm{u}=\% 2$ Fcitations\%3Fview_op\%3Dview_citation\%26hl\%3Den\%26user\%3Deo91IMAAAAJ\%26citation_for_view\%3D-eo91IMAAAAJ\%3A9yKSN-GCB0IC\%26tzom\%3D480.

12 Ibid. 
bertahap, yaitu dimulai dari tidak mampu, kurang mampu, sampai siswa menjadi mampu dalam memberikan bukti di bidang geometri, khususnya pada materi kesebangunan dua segitiga.

\section{Metode}

Penelitian ini adalah penelitian kualitatif deskriptif. Penelitian ini terdiri dari dua tahap. Tahap pertama adalah menentukan subjek penelitian. Penentuan subjek penelitian dilakukan dengan meminta 51 siswa sekolah menengah pertama kelas IX di dua sekolah negeri untuk menyelesaikan masalah kesebangunan dua segitiga (lihat Gambar 1). Setelah berhasil menyelesaikan masalah kesebangunan dua segitiga, maka selanjutnya mengelompokkan jawaban siswa berdasarkan kategori mampu, kurang mampu, dan belum mampu. Dimana kategori mampu adalah siswa yang berhasil memberikan bukti secara lengkap dan benar. Kategori kurang mampu adalah siswa yang benar dalam memberikan bukti, tetapi kurang lengkap dalam memberikan bukti. Sedangkan kategori tidak mampu adalah siswa yang gagal dalam memberikan bukti. Dari hasil penelitian pendahuluan diperoleh dari 51 siswa sekolah menengah pertama yang menyelesaikan masalah kesebangunan dua segitiga (lihat Gambar 1) diperoleh 26 siswa berada dalam kategori mampu, 17 siswa berada dalam kategori kurang mampu, dan 8 siswa berada dalam kategori tidak mampu. Selanjutnya dari masing-masing kategori tersebut diambil satu subjek penelitian untuk didalami lebih lanjut.

Tahap kedua adalah menganalisis kemampuan pembuktian dari siswa mampu, kurang mampu, dan belum mampu dalam membuktikan kesebangunan dua segitiga berdasarkan tiga tinjauan, yaitu : (1) pemahaman atau pengetahuan matematis yang digunakan dalam membuktikan kesebangunan dua segitiga, (2) representasi dari bukti yang diberikan oleh siswa, dimana representasi yang diberikan bisa berupa bukti visual, bukti simbolis, dan bukti secara formal (lihat Tabel 1), (3) asumsi matematis dan asumsi logis yang digunakan oleh siswa dalam membuktikan kesebangunan dua segitiga. Dari hasil analisis ini, maka akan ditemukan bagaimana pengetahuan matematis, representasi, dan asumsi dari siswa mampu, kurang mampu, dan belum mampu untuk menyalesaikan masalah pembuktian kesebangunan dua segitiga. 


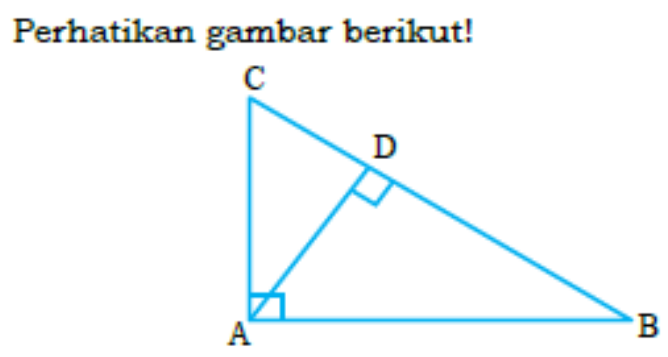

Gambar 2. Segitiga Siku-siku

Jika garis $A D$ adalah garis tinggi, maka panjang $\mathrm{AD}^{2}=\mathrm{CD} \times \mathrm{BD}$.

a. Benarkah pernyataan di atas?

b. Berilah bukti atau alasan dari jawaban kalian!

Sumber: Setiawan, dkk, (2016)

\section{Gambar 1. Instrumen Penelitian}

Instrumen yang digunakan dalam penelitian adalah soal nomor 2 (lihat Gambar 1) dari paket tes geometri untuk mengukur keterampilan berpikir kritis siswa sekolah menengah pertama yang dikembangkan oleh Setiawan, Sunardi, \& Kusno ${ }^{13}$. Alasan peneliti memilih instrumen tersebut, yaitu soal merupakan materi tentang kesebangunan dua segitiga, soal merupakan level menganalisis pada taksonomi Bloom yang telah direvisi. Karakteristik dari soal merupakan soal tentang pembuktian. Selain itu, soal-soal yang dikembangkan oleh Setiawan, Sunardi, dan Kusno telah memenuhi syarat soal tes yang baik, yaitu: valid secara teoritis dan valid empiris, memiliki daya beda, dan memenuhi reliabilitas. Hasil diseminasi atau perluasan dari paket tes juga memenuhi reliabilitas. soal-soal pada paket tes telah memenuhi unsur kepraktisan, terutama petunjuk mengerjakan soal dan kalimat yang ada dalam soal mudah dipahami oleh siswa ${ }^{14}$. Jadi soal pada Gambar 1 dapat digunakan untuk mengukur kemampuan membuktikan kesebangunan dua segitiga pada siswa kelas IX sekolah menengah pertama.

\section{Hasil dan Diskusi}

Sesuai dengan prosedur penelitian ini. Tahap pertama adalah mengelompokkan jawaban siswa berdasarkan kategori kemampuan pembuktian yang terdiri dari mampu, kurang mampu dan belum mampu dengan menggunakan rubrik penilaian paket tes Geometri untuk mengukur keterampilan berpikir kritis. Pengelompokan jawaban berdasarkan ketiga

13 Ibid.

${ }^{14}$ Yayan Eryk Setiawan, "Ketercapaian Indikator Keterampilan Dasar Dalam Berpikir Kritis Pada Siswa SMP," Jurnal Pendidikan Dan Pengembangan Profesi 6, no. 2 (2016): 24251. 
kategori tersebut dari 51 siswa sekolah menengah pertama kelas IX di dua sekolah Negeri dapat dilihat pada Tabel 2.

Tabel 2. Kategori Kemampuan Pembuktian

\begin{tabular}{ccr}
\hline \multicolumn{1}{c}{ Kategori kemampuan } & Banyaknya siswa & Persentase \\
\hline Mampu & 26 & $50,98 \%$ \\
Kurang mampu & 17 & $33,33 \%$ \\
Belum mampu & 8 & $15,69 \%$ \\
\hline Total & 51 & $100 \%$ \\
\hline
\end{tabular}

Tahap kedua adalah melakukan analisis terhadap jawaban yang diberikan siswa dalam membuktikan kesebangunan dua segitiga (lihat Gambar 1) berdasarkan kategori mampu, kurang mampu, dan belum mampu. Analisis berdasarkan ketiga kategori tersebut ditinjau dari tiga hal, yaitu: (1) pengetahuan dan/atau pemahaman matematis yang digunakan, (2) representasi bukti yang digunakan, dan (3) asumsi matematis dan logis yang digunakan.

Analisis pertama adalah siswa yang mampu membuktikan kesebanguan dua segitiga. Ada 26 siswa yang mampu membuktikan masalah kesebangunan dua segitiga pada Gambar 1. Salah satu jawaban siswa (selanjutnya subjek penelitian) dengan kategoti mampu dapat dilihat pada Gambar 2. Tinjauan yang pertama dari kemampuan subjek dalam membuktikan kesebangunan dua segitiga adalah berdasarkan pengetahuan dan/atau pemahaman matematis yang digunakan. Jika kita lihat pada langkah pertama dari Gambar 2, diketahui bahwa subjek menggunakan pemahaman matematis tentang teorema Pythagoras, dimana subjek memulai pembuktian dari segitiga sikusiku ABC. Pada langkah kedua, subjek mengubah BC menjadi (BD + DC), kemudian menjabarkan $(B D+D C)^{2}$ pada langkah ketiga, ini merupakan pengetahuan matematis yang berkaitan dengan perkalian aljabar. Pada langkah keempat, mengubah $A C^{2}$ menjadi $A D^{2}+D C^{2}$ serta mengubah $A B^{2}$ menjadi $A D^{2}+B D^{2}$, ini juga merupakan pengetahun tentang teorema Pythagoras. Pada langkah kelima dan keenam subjek menggunakan prinsip kesetaraan (ekuivalensi), sehingga diperoleh $A D^{2}=B D \times D C$. Akhirnya subjek membuat kesimpulan bahwa $A D^{2}=B D \times D C$ terbukti. Jadi diperoleh pengetahuan matematis yang digunakan oleh subjek dengan kategori mampu dalam membuktikan kesebangunan dua segitiga antara lain: pengetahuan tentang teorema Pythagoras, pengetahuan tentang operasi aljabar, dan pengetahuan tentang prinsip kesetaraan (ekuivalensi). 


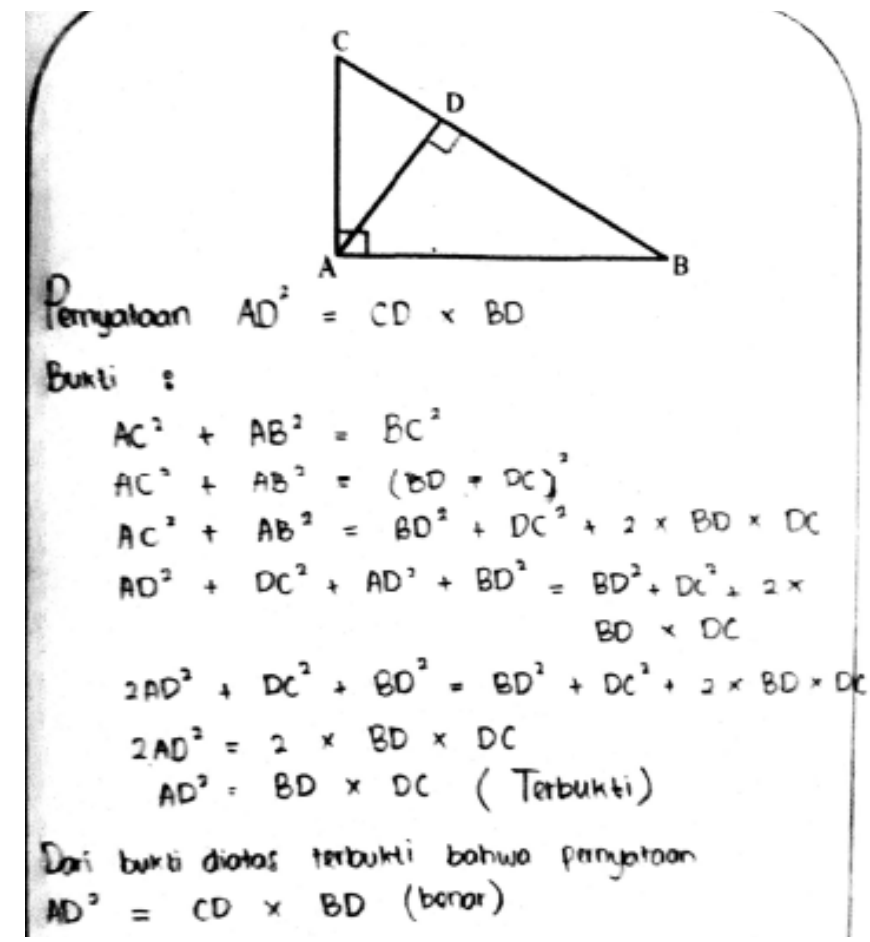

Gambar 2. Contoh Hasil Siswa (Subjek) Mengerjakan dengan Benar

Tinjauan yang kedua dari jawaban subjek berdasarkan representasi bukti yang digunakan oleh subjek. Jika kita melihat pembuktian subjek pada Gambar 2, subjek merepresentasikan bukti dengan menggunakan manipulasi aljabar yang merupakan bukti simbolis. Tinjauan yang ketiga berdasarkan asumsi yang digunakan oleh subjek dalam membuktikan kesebangunan dua segitiga. Subjek menggunakan asumsi logis, yaitu menggunakan segitiga sikusiku. Bukti yang diberikan oleh subjek merupakan bukti formal, yaitu bukti langsung dengan menggunakan bukti implikasi, jika $\mathrm{P}$ maka $\mathrm{Q}$, dimana $\mathrm{P}$ adalah pernyataan segitiga siku-siku bernilai benar dan $\mathrm{Q}$ adalah pernyataan $A D^{2}=B D \times D C$ yang telah dibuktikan oleh subjek juga benar. Jadi asumsi subjek telah logis, terutama dalam tahapan-tahapan pembuktian kesebangunan dua segitiga.

Dari hasil analisis kemampuan subjek dalam melakukan pembuktian berdasarkan kemampuan matematis, representasi, dan asumsi diperoleh bahwa subjek yang mampu melakukan pembuktian memiliki pemahaman dan/atau pengetahuan matematis dasar yang berupa teorema Pythagoras, operasi aljabar, dan prinsip kesetaraan. Sedangkan representasi yang digunakan merupakan bukti simbolis dan bukti formal (teruma bukti langsung). Serta asumsi yang digunakan adalah logis, yaitu sesuai dengan tahapan-tahapan pembuktian. 
Analisis yang kedua dilakukan terhadap siswa yang kurang mampu dalam melakukan pembuktian. Ada 17 siswa dengan kategori kurang mampu, yaitu sebagian bukti yang diberikan tidak ada. Salah satu contoh hasil pengerjaan siswa (selanjutnya merupakan subjek penelitian) yang kurang mampu dalam melakukan pembuktian dapat dilihat pada Gambar 3.

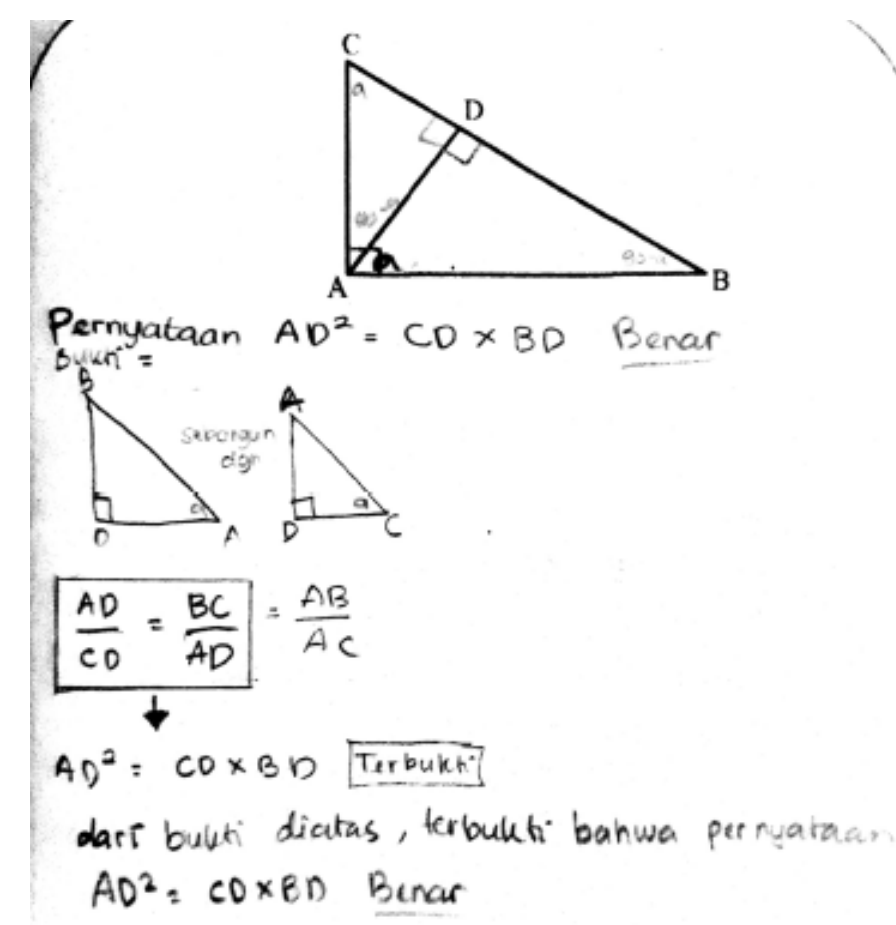

Gambar 3. Contoh Hasil Pengerjaan Siswa (Subjek) Kurang Mampu

Tinjauan yang pertama dari kemampuan subjek dalam membuktikan kesebangunan dua segitiga adalah berdasarkan pengetahuan dan/atau pemahaman matematis yang digunakan. Jika kita lihat pada langkah pertama dari Gambar 3 dapat diketahui bahwa subjek menggunakan pemahaman tentang kesebangunan segitiga, tetapi subjek tidak terlebih dahulu membuktikan bahwa ketiga segitiga tersebut adalah sebangun. Dalam hal ini subjek memiliki pengetahuan matematis berupa kesebangunan, tetapi tidak membuktikan terlebih dahulu tentang kesebangunan. Pada langkah kedua diperoleh dengan membandingkan sisi-sisi yang bersesuaian. Kemudian pada langkah ketiga mengambil perbandingan $\frac{A D}{C D}=\frac{B C}{A D}$ yang dilanjutkan dengan melakukan perkalian silang atau prinsip kesetaraan, sehingga diperoleh $A D^{2}=B D \times D C$. Akhirnya subjek membuat kesimpulan bahwa $A D^{2}=B D \times$ $D C$ terbukti. Jadi pengetahuan matematis yang digunakan oleh subjek dalam membuktikan kesebangunan dua segitiga adalah pengetahuan tentang kesebangunan (namun pembuktian kesebangunan tidak ada, hanya 
mengasumsikan bahwa bangun sebangun), pengetahuan tentang perbandingan, dan pengetahuan tentang prinsip kesetaraan.

Tinjauan yang kedua dari jawaban subjek adalah representasi dari bukti yang diberikan oleh subjek. Jika kita melihat pembuktian subjek pada Gambar 3 , subjek merepresentasikan dengan bukti visual yaitu subjek melibatkan gambar yang dapat kita lihat pada langkah pertama pembuktian. Tinjauan yang ketiga berdasarkan asumsi, subjek menggunakan asumsi kesebangunan dua segitiga, namun kesebangunan tersebut tidak dibuktikan terlebih dahulu oleh subjek. Bukti yang dilakukan oleh subjek merupakan bukti formal, yaitu bukti langsung menggunakan bukti implikasi, jika $\mathrm{P}$ maka $\mathrm{Q}$ dimana $\mathrm{P}$ adalah pernyataan dua segitiga yang sebangun dan $Q$ adalah pernyataan $A D^{2}=B D \times D C$ yang telah dibuktikan oleh subjek juga benar. Jadi subjek memiliki asumsi logis yang sesuai dengan tahapan-tahapan pembuktian kesebangunan dua segitiga.

Dari hasil analisis kemampuan subjek dalam melakukan pembuktian kesebangunan dua segitiga, maka diperoleh bahwa subjek yang kurang mampu memiliki pengetahuan dan/atau pemahaman matematis dasar yang berupa kesebangunan (namun tidak dibuktikan terlebih dahulu oleh subjek), pengetahuan tentang perbandingan, pengetahuan tentang prinsip kesetaraan (ekuivalensi). Kemudian representasi yang digunakan adalah bukti visual dan bukti formal (teruma bukti langsung). Sedangkan asumsi yang digunakan dalam pembuktian adalah asumsi logis, yaitu sesuai dengan tahapan-tahapan pembuktian.

Analisis yang ketiga dilakukan terhadap jawaban siswa yang belum mampu dalam melakukan pembuktian kesebangunan dua segitiga. Ada 8 siswa yang belum mampu membuktikan kesebangunan dua segitiga. Salah satu contoh hasil pengerjaan siswa (selanjutnya adalah subjek penelitian) yang belum mampu dalam melakukan pembuktian kesebangunan dua segitiga dapat dilihat pada Gambar 4. Analisis yang pertama dari kemampuan subjek dalam membuktikan kesebangunan dua segitiga adalah berdasarkan pengetahuan dan/atau pemahaman matematis yang digunakan. Jika dilihat pada langkah pertama dari Gambar 4 dapat diketahui bahwa subjek menggunakan pemahaman matematis yang salah dalam melakukan pembuktian, kemudian subjek mengalami kesulitan dalam melakukan pembuktian berikutnya. Secara langsung subjek mengatakan pernyataan tersebut benar. Jadi pengetahuan matematis yang digunakan oleh subjek yang belum mampu melakukan pembuktian kesebangunan dua segitiga adalah pengetahuan dan/atau pemahaman matematis yang salah atau tidak relevan untuk memberikan jawaban yang berupa bukti, sehingga subjek kesulitan untuk melakukan langkah pembuktian berikutnya. 

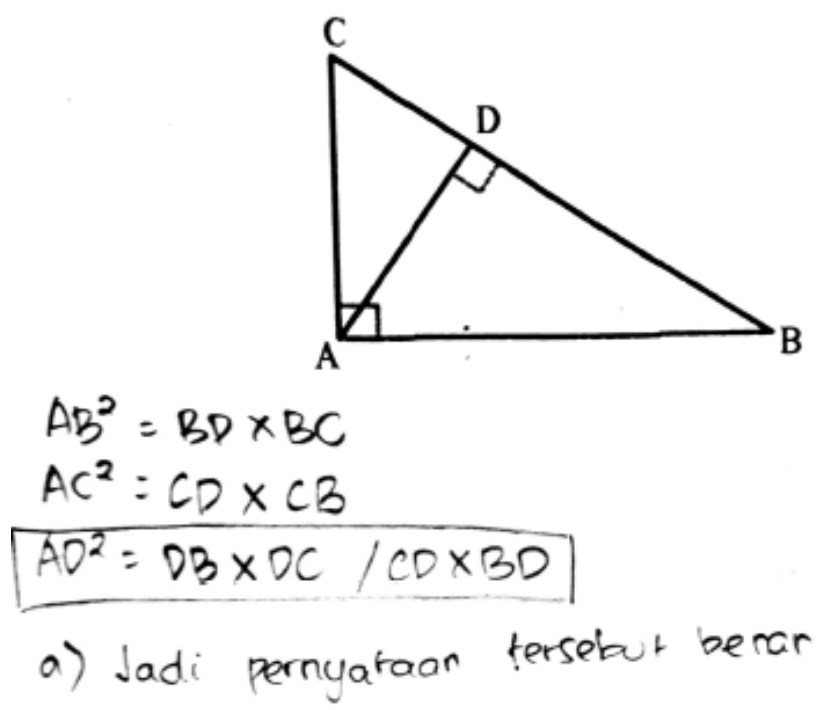

Gambar 4. Contoh Hasil Pengerjaan Siswa (Subjek) yang Belum Mampu

Analisis yang kedua dari jawaban subjek ditinjau dari representasi bukti yang digunakan oleh subjek yang belum mampu. Jika kita melihat pembuktian subjek pada Gambar 4 dapat diketahui bahwa subjek merepresentasikan dengan bukti simbolis, tetapi masih salah dalam melakukan manipulasi aljabar. Analisis yang ketiga berdasarkan asumsi yang digunakan dalam membuktikan kesebangunan dua segitiga. Diperoleh bahwa subjek yang belum mampu melakukan pembuktian kesebangunan dua segitiga menggunakan asumsi yang salah atau tidak relevan, sehingga bukti yang diberikan kurang logis. Dilihat dari keformalan, bukti yang diberikan tidak formal.

Dari analisis kemampuan subjek yang kurang mampu dalam melakukan pembuktian kesebangunan dua segitiga, diperoleh bahwa subjek yang belum mampu melakukan pembuktian memiliki pemahaman dan/atau pengetahuan matematis dasar yang salah atau tidak relevan dalam mendukung pembuktian. Representasi yang digunakan merupakan bukti simbolis, tetapi salah dalam melakukan manipulasi aljabar dan bukti tidak formal. Serta asumsi yang digunakan oleh subjek yang belum mampu dalam melakukan pembuktian adalah kurang logis atau tidak logis.

Dari hasil analisis deskriptif terhadap jawaban subjek yang mampu, subjek yang kurang mampu, dan subjek yang belum mampu dalam membuktikan kesebangunan dua segitiga, maka diperoleh perbandingan kemampuan ketiga kategori berdasarkan pengetahuan matematis dasar yang digunakan dalam pembuktian, representasi pembuktian, serta asumsi yang digunakan dalam pembuktian dapat dilihat pada Tabel 3. 
Tabel 3. Kemampuan Pembuktian Kesebangunan Dua Segitiga

\begin{tabular}{|c|c|c|c|}
\hline \multirow[b]{2}{*}{ Kategori } & \multicolumn{3}{|c|}{ Kemampuan Pembuktian } \\
\hline & $\begin{array}{l}\text { Pengetahuan Matematis } \\
\text { Dasar }\end{array}$ & Representasi & Asumsi \\
\hline Mampu & $\begin{array}{l}\text { Pengetahuan dan/atau } \\
\text { pemahaman matematis } \\
\text { dasar yang digunakan } \\
\text { dalam pembuktian } \\
\text { kesebangunan dua segitiga } \\
\text { terdiri dari: teorema } \\
\text { Pythagoras, pengetahuan } \\
\text { tentang operasi aljabar, } \\
\text { dan pengetahuan tentang } \\
\text { prinsip kesetaraan } \\
\text { (ekuivalensi). }\end{array}$ & $\begin{array}{l}\text { Representasi yang } \\
\text { digunakan } \\
\text { merupakan bukti } \\
\text { simbolis (yaitu } \\
\text { bukti manipulasi } \\
\text { aljabar) dan bukti } \\
\text { formal (terutama } \\
\text { bukti langsung). }\end{array}$ & $\begin{array}{l}\text { Asumsi yang } \\
\text { digunakan } \\
\text { dalam } \\
\text { pembuktian } \\
\text { adalah asumsi } \\
\text { logis, yaitu } \\
\text { sesuai dengan } \\
\text { tahapan- } \\
\text { tahapan } \\
\text { pembuktian. }\end{array}$ \\
\hline $\begin{array}{l}\text { Kurang } \\
\text { mampu }\end{array}$ & $\begin{array}{l}\text { Pengetahuan dan/atau } \\
\text { pemahaman matematis } \\
\text { dasar yang digunakan } \\
\text { dalam pembuktian } \\
\text { kesebangunan dua segitiga } \\
\text { terdiri dari: kesebangunan } \\
\text { (yang tidak dibuktikan } \\
\text { terlebih dahulu), } \\
\text { pengetahuan tentang } \\
\text { perbandingan, } \\
\text { pengetahuan tentang } \\
\text { prinsip kesetaraan. }\end{array}$ & $\begin{array}{l}\text { Representasi yang } \\
\text { digunakan } \\
\text { merupakan bukti } \\
\text { visual } \\
\text { (menggunakan } \\
\text { gambar) dan } \\
\text { bukti formal } \\
\text { (terutama bukti } \\
\text { langsung). }\end{array}$ & $\begin{array}{l}\text { Asumsi yang } \\
\text { digunakan } \\
\text { dalam } \\
\text { pembuktian } \\
\text { adalah asumsi } \\
\text { logis, yaitu } \\
\text { sesuai dengan } \\
\text { tahapan- } \\
\text { tahapan } \\
\text { pembuktian. }\end{array}$ \\
\hline $\begin{array}{l}\text { Belum } \\
\text { mampu }\end{array}$ & $\begin{array}{l}\text { Pengetahuan dan/atau } \\
\text { pemahaman matematis } \\
\text { dasar yang digunakan } \\
\text { dalam pembuktian } \\
\text { kesebangunan dua segitiga } \\
\text { adalah salah atau tidak } \\
\text { relevan dalam mendukung } \\
\text { pembuktian. }\end{array}$ & $\begin{array}{l}\text { Representasi yang } \\
\text { digunakan } \\
\text { merupakan bukti } \\
\text { simbolis, tetapi } \\
\text { salah dalam } \\
\text { melakukan } \\
\text { manipulasi } \\
\text { aljabar dan bukti } \\
\text { tidak formal. }\end{array}$ & $\begin{array}{l}\text { Asumsi yang } \\
\text { digunakan } \\
\text { dalam } \\
\text { pembuktian } \\
\text { adalah tidak } \\
\text { logis, yaitu } \\
\text { tidak sesuai } \\
\text { dengan } \\
\text { tahapan- } \\
\text { tahapan } \\
\text { pembuktian. }\end{array}$ \\
\hline
\end{tabular}

Dari Tabel 3 dapat diketahui bahwa subjek yang mampu dalam melakukan pembuktian kesebangunan dua segitiga cenderung menggunakan pengetahuan matematis yang berupa teorema Pythagoras, operasi aljabar, dan ekuivalensi. Temuan penting dalam penelitian ini adalah tidak ada subjek dalam pembuktian ini menggunakan pengetahuan tentang kesebangunan. Ini artinya subjek yang mampu melakukan pembuktian lebih menyukai 
pembuktian dengan menggunakan operasi aljabar, terutama manipulasi aljabar. Hal ini sesuai dengan hasil penelitian yang menunjukkan bahwa keunggulan siswa sekolah menengah pertama dalam memberikan bukti adalah dapat memberikan bukti dengan rumus ${ }^{15}$. Akibat pengetahuan tentang operasi aljabar ini, maka representasi yang digunakan oleh subjek dengan kategori mampu adalah bukti simbolis. Sedangkan asumsi yang digunakan adalah asumsi logis, yaitu sesuai tahap-tahap pembuktian yang masuk akal. Hal ini sesuai dengan hasil penelitian yang menunjukkan bahwa sebagian siswa sekolah menengah pertama dapat berpikir logis ${ }^{16}$.

Dari Tabel 3 juga diperoleh bahwa subjek yang kurang mampu dalam melakukan pembuktian kesebangunan dua segitiga cenderung menggunakan pengetahuan matematis yang berupa kesebangunan, perbandingan, dan ekuivalensi. Temuan penting dalam penelitian ini adalah subjek masih kesulitan dalam membuktikan kesebangunan. Kesulitan ini disebabkan membutuhkan kemampuan analisis gambar secara teliti saat menggunakan kesebangunan. Hasil penelitian menunjukkan bahwa kebanyakan siswa kelas VIII sekolah menengah pertama dapat membuat bukti secara benar yang biasanya berdasarkan pada segitiga sebangun dan pembuktian secara langsung $^{17}$. Akibat dari pengetahuan yang dimiliki yang berupa kesebangunan, maka representasi yang digunakan adalah berupa bukti visual, yaitu menggunakan gambar dua segitiga yang sebangun. Sedangkan asumsinya adalah asumsi logis, yaitu sesuai dengan tahapan pembuktian.

Dari Tabel 3 juga dapat diketahui bahwa subjek yang belum mampu dalam melakukan pembuktian kesebangunan dua segitiga cenderung menggunakan pengetahuan dan/atau pemahaman matematis yang salah, hal sesuai dengan hasil penelitian yang mengatakan bahwa kegagalan pembuktian dalam geometri salah satunya adalah kegagalan dugaan (failed conjecture) yaitu dugaan yang didasarkan pada sifat-sifat gambar tidak sesuai18. Hasil penelitian menunjukkan bahwa jenis-jenis kesalahan yang dilakukan siswa dalam menyelesaikan soal-soal kesebangunan, meliputi kesalahan konsep, kesalahan prosedur, dan kesalahan kecerobohan, sedangkan yang menjadi faktor penyebab kesalahan siswa adalah siswa kurang menguasai materi, kurang teliti, kurang menguasai materi prasyarat,

15 Yayan Eryk Setiawan and Sunardi, "Profil Keterampilan Berpikir Kritis Siswa SMP."

16 Ibid.

17 Taro Fujita and Keith Jones, "Reasoning-and-Proving in Geometry in School Mathematics Textbooks in Japan," International Journal of Educational Research 64 (2014): 81-91.

18 Madona Chartouny, Iman Osta, and Nawal Abou Raad, "A Framework for Failed Proving Processes in a Dynamic Geometry Environment," Mathematics and Technology, 2017, 225. 
serta tidak memahami langkah menyelesaikan soal19. Akibat dari pengetahuan matematis yang salah atau tidak relevan adalah kesulitan dalam langkah pembuktian berikutnya, yang berakibat bukti yang diberikan salah. Representasi yang digunakan adalah simbolis yang salah dan asumsi yang diberikan juga kurang logis. Hasil penelitian menunjukkan bahwa kekurangan siswa sekolah menengah pertama dalam hal pembuktian adalah kurang dapat memberikan bukti berupa alasan yang $\operatorname{logis}^{20}$. Secara keseluruhan pembuktian siswa yang belum mampu ini mengarah kepada kegagalan pembuktian. Dimana kegagalan dalam pembuktian (failed proof) merupakan kesalahan dalam pembuktian, buktinya tidak lengkap, menggunakan sifatsifat yang salah, mengasumsikan sifat yang diamati pada gambar sebagai hipotesis, atau terlalu banyak kesimpulan karena tidak menyajikan argumen yang cukup ${ }^{21}$.

Temuan penting lainnya adalah tugas khusus geometri tidak hanya memerlukan pengetahuan konten, tetapi juga memerlukan pengetahuan tentang operasi aljabar, perbandingan, dan kesetaraan. Hal ini sesuai dengan hasil penelitian yang menunjukkan bahwa pelatihan kognitif saja tidak memadai untuk membuat perbaikan yang signifikan pada kinerja siswa ${ }^{22}$ Hasil penelitian lainnya juga menunjukkan bahwa ketika postulat kongruensi segitiga diperkenalkan, peserta menunjukkan peningkatan yang luar biasa pada pembuktian kekongruenan dua segitiga. Selain pengetahuan matematis, berbagai representasi pembuktian juga diperlukan untuk dibelajarkan kepada siswa. Dari berbagai representasi tersebut, siswa akan memilih menggunakan representasi yang mudah menurut siswa. Asumsi logis juga perlu ditekankan kepada siswa dengan cara mengevaluasi tahapan-tahapan pembuktian. Dari evaluasi tahapan pembuktian, akan diketahui kelogisan sebuah pembuktian. Jadi pada intinya, dalam pembuktian harus menerapkan tiga hal penting, yaitu pengetahuan dan/atau kemampuan matematis apa saja yang dibutuhkan, berbagai representasi dari pembuktian, dan asumsi matematis serta asumsi logis dari pembuktian.

19 Titi Solfitri and Yenita Roza, "Analisis Kesalahan Dalam Menyelesaikan Soal-Soal Geometri Siswa Kelas IX SMPN Se-Kecamatan Tampan Pekanbaru," SEMIRATA 2015 1, no. 1 (2015).

20 Yayan Eryk Setiawan and Sunardi, "Profil Keterampilan Berpikir Kritis Siswa SMP."

21 Chartouny, Osta, and Raad, "A Framework for Failed Proving Processes in a Dynamic Geometry Environment."

22 Dake Zhang, "Effects of Visual Working Memory Training and Direct Instruction on Geometry Problem Solving in Students with Geometry Difficulties.," Learning Disabilities: $A$ Contemporary Journal 15, no. 1 (2017): 117-138. 


\section{Kesimpulan}

Hasil penelitian ini berkonstribusi pada pengetahuan dan/atau pemahaman matematis, representasi, dan asumsi logis yang dibutuhkan dalam pembuktian kesebangunan dua segitiga. Siswa yang mampu memberikan bukti dengan benar memiliki pengetahuan matematis dasar yang benar dan relevan untuk mendukung pembuktian. Sedangkan siswa yang belum mampu melakukan pembuktian memiliki pengetahuan matematis dasar yang salah atau tidak relevan dalam mendukung pembuktian. Meskipun penelitian ini terbatas hanya tiga subjek, tetapi penelitian ini telah berkonstribusi pada diketahuinya pengetahuan dan/atau pemahaman matematis, representasi, dan asumsi yang dibutuhkan untuk membuktikan kesebangunan dua segitiga. Penelitian selanjutnya dapat menganalisis berbagai pembuktian pada materi lain. Rekomendasi terhadap pendidik dalam melakukan pembelajaran pembuktian yaitu membekali siswa dengan berbagai pengetahuan matematis dasar yang benar dan relevan untuk mendukung pembuktian; membekali siswa dengan berbagai representasi bukti, antara lain bukti simbolis, bukti visual, serta bukti formal; membekali siswa untuk memiliki asumsi logis melalui tahap-tahap pembuktian yang benar serta aturan logika yang sesuai dengan jenjang pendidikan.

\section{Daftar Pustaka}

Chartouny, Madona, Iman Osta, and Nawal Abou Raad. "A Framework for Failed Proving Processes in a Dynamic Geometry Environment." Mathematics and Technology, 2017, 225.

Djumanta, Wahyudin, and Dwi Susanti. Belajar Matematika Aktif Dan Menyenangkan. Jakarta: Grasindo, 2008.

Ernest, Paul, Ole Skovsmose, Jean Paul Van Bendegem, Maria Bicudo, Roger Miarka, Ladislav Kvasz, and Regina Moeller. "The Philosophy of Mathematics Education," 1991.

Fujita, Taro, and Keith Jones. "Reasoning-and-Proving in Geometry in School Mathematics Textbooks in Japan." International Journal of Educational Research 64 (2014): 81-91.

Knuth, Eric J. "Secondary School Mathematics Teachers' Conceptions of Proof." Journal for Research in Mathematics Education, 2002, 379-405.

Mathematics, Research Advisory Committee of the National Council of Teachers of. "NCTM Curriculum and Evaluation Standards for School Mathematics: Responses from the Research Community." Journal for Research in Mathematics Education 19, no. 4 (1988): 338-44. https://doi.org/10.2307/749544.

Solfitri, Titi, and Yenita Roza. "Analisis Kesalahan Dalam Menyelesaikan SoalSoal Geometri Siswa Kelas IX SMPN Se-Kecamatan Tampan Pekanbaru." SEMIRATA 20151, no. 1 (2015). 
Stylianou, Despina A., Maria L. Blanton, and Eric J. Knuth, eds. Teaching and Learning Proof Across the Grades: A K-16 Perspective. 1 edition. New York: Routledge, 2009.

Subchan, Winarni, Lukman Hanafi, M. Syifa'ul Mufid, Kistosil Fahim, and Wawan Hafid Syaifudin. Matematika SMP/MTs Kelas IX - Semester 1 Kurikulum 2013 - Edisi Revisi 2015. Jakarta: Kementerian Pendidikan dan Kebudayaan, 2018. https://www.myedisi.com/bse/25202/matematika.

Tall, David. "Cognitive Development, Representations and Proof." In Proceedings of the Conference Justifying and Proving in School Mathematics, 27:38, 1995.

Yayan Eryk Setiawan. "Ketercapaian Indikator Keterampilan Dasar Dalam Berpikir Kritis Pada Siswa SMP." Jurnal Pendidikan Dan Pengembangan Profesi 6, no. 2 (2016): 242-51.

Yayan Eryk Setiawan, and Sunardi. "Profil Keterampilan Berpikir Kritis Siswa SMP," 1:933-42. Malang: Program Studi S2-S3 Pendidikan Matematika Pascasarjana Universitas Negeri Malang, 2016. https://scholar.google.co.id/citations?user=eo91IMAAAAJ\&hl=en\#d=gs_md_cita$\mathrm{d} \& \mathrm{u}=\% 2 \mathrm{Fcitations} \% 3 \mathrm{Fview}$ _op\%3Dview_citation\%26hl\%3Den\%26us er\%3D-eo91IMAAAAJ\%26citation_for_view\%3Deo91IMAAAAJ\%3A9yKSN-GCB0IC\%26tzom\%3D-480.

Zhang, Dake. "Effects of Visual Working Memory Training and Direct Instruction on Geometry Problem Solving in Students with Geometry Difficulties." Learning Disabilities: A Contemporary Journal 15, no. 1 (2017): 117-138. 